\title{
The role of RNA interference in the developmental separation of blood and lymphatic vasculature
}

\author{
Vascular Cell 6:9 | DOI: 10.1186/2045-824X-6-9 ｜（C) Li et al.; licensee Publiverse Online S.R.L. 2014 \\ Received: 2 Oct 2013 | Accepted: 25 Oct 2014 I Published: 1 Oct 2014 \\ Gauvrit Sébastien, Philippe Josette, Lesage Matthieu, Tjwa Marc, Godin Isabelle, Germain Stéphane ${ }^{@}$ \\ ${ }^{+}$Contributed equally ${ }^{@}$ Corresponding author
}

\begin{abstract}
Background

Dicer is an RNase III enzyme that cleaves double stranded RNA and generates functional interfering RNAs that act as important regulators of gene and protein expression. Dicer plays an essential role during mouse development because the deletion of the dicer gene leads to embryonic death. In addition, dicer-dependent interfering RNAs regulate postnatal angiogenesis. However, the role of dicer is not yet fully elucidated during vascular development.
\end{abstract}

\section{Methods}

In order to explore the functional roles of the RNA interference in vascular biology, we developed a new constitutive $\mathrm{Cre} /$ loxP-mediated inactivation of dicer in tie 2 expressing cells.

\section{Results}

We show that cell-specific inactivation of dicer in Tie2 expressing cells does not perturb early blood vessel development and patterning. Tie 2 -Cre; dicer ${ }^{f l f l}$ mutant embryos do not show any blood vascular defects until embryonic day (E)12.5, a time at which hemorrhages and edema appear. Then, midgestational lethality occurs at E14.5 in mutant embryos. The developing lymphatic vessels of dicer -mutant embryos are filled with circulating red blood cells, revealing an impaired separation of blood and lymphatic vasculature.

\section{Conclusion}

Thus, these results show that RNA interference perturbs neither vasculogenesis and developmental angiogenesis, nor lymphatic specification from venous endothelial cells but actually provides evidence for an epigenetic control of separation of blood and lymphatic vasculature.

\section{Keywords}

Dicer - Lymphangiogenesis - Veino-lymphatic separation - Angiogenesis - RNA interference

\section{Background}

RNA interference (RNAi) is a gene silencing pathway by which specific messenger RNAs (mRNAs) are either degraded or translationally suppressed [ 1]. It is mediated by microRNA (miRNA) or short interfering RNA (siRNA), both non coding RNAs of 20-22 nucleotides which are matured by the RNase Dicer and are involved in base pairing with target mRNAs. In mice, dicer is critical for early mouse development because its abrogation prevents the production of functional interfering RNAs resulting in embryonic lethality at E7.5 [2]. A second study reported death at E13.5 which was associated with angiogenesis defects [ 3] but both studies were unable to decipher the role of Dicer in specific vascular cell types. Conditional ablation of dicer developed to investigate its function in limb buds [ 4], in immune cells [ 5], and heart development [ 6] have suggested important roles of RNA interference in various biologic processes such as cell survival, proliferation, differentiation, and maintenance of cell function.

In angiogenesis, the role of Dicer-regulated miRNAs was further suggested in mice expressing a hypomorphic Dicer 1 allele, which resulted in female infertility caused by corpus luteum insufficiency and defective ovarian angiogenesis [ 
7]. In addition, Dicer has been shown to have multiple roles in vascular biology. Tamoxifen-inducible and smooth muscle cell (SMC)-specific deletion of Dicer achieved by Cre-Lox recombination showed that miRNAs are necessary for vascular smooth muscle growth, differentiation, and function [ 8,9]. Dicer-deficient mice exhibited a dramatic reduction in blood pressure due to significant loss of vascular contractile function and SMC contractile differentiation as well as vascular remodeling. This phenotype pointed to miRNAs as important mediators for the modulation of the VSMC phenotype by targeting transcription factors and the cytoskeleton, which acts as molecular switches for VSMC differentiation [ 10]. In these cells, the Mir143/145 gene cluster plays a major role in regulating the contractile phenotype and controling responses to various types of injury [ 11-13].

The reduction of endothelial miRNAs by inactivation of Dicer both in vitro [ 14] and in vivo using Cre-recombinase under the regulation of tie 2 promoter/enhancer or tamoxifen inducible expressed Cre-recombinase $\left(\mathrm{Cre}^{-E^{\mathrm{T} 2}}\right) \mathrm{under}$ the regulation of vascular endothelial cadherin promoter was shown to reduce postnatal angiogenic response to a variety of stimuli, including exogenous VEGF, tumors, limb ischemia, and wound healing [ 15]. In vitro studies demonstrated the presence of miRNAs in endothelial cells $[16,17]$ and silencing of Dicer using short interfering (si)RNA in human endothelial cells resulted in impaired capillary-like structures and reduced cell growth [ 18-21]. The angiogenic properties of members of the mir 17-92 cluster have been extensively studied [ 15, 22, 23]. Also, miR-92a, miR-15a, miR-126 were identified to target mRNAs corresponding to several proangiogenic proteins, such as FGF2 and VEGF [ 22, 24- 28]. In addition, recent studies reported the role of miR-99b, miR-181a, and miR-181b in the differentiation of human embryonic stem cells to vascular endothelial cells [29]. In the vascular endothelium, recent findings have shown that miRNAs such as mir-210 orchestrate the response to hypoxia [ 30, 31] and that downregulation of Dicer under chronic hypoxia is an adaptive mechanism that serves to maintain the cellular hypoxic response through HIF- $\alpha$ and miRNA-dependent mechanisms [ 29]. Functional deficiency of Dicer in chronic hypoxia is relevant to both HIF- $\alpha$ isoforms and hypoxia-responsive/HIF target genes. The regulation of Prox 1 by miR-181 further highlighted the contribution of RNA interference in the induction of lymphatic endothelium. Indeed, miR-181 is highly expressed in the blood vasculature, but significantly reduced in lymphatic endothelial cells, reciprocally to Prox1 expression [ 32].

However, whether Dicer could regulate angiogenesis, especially during development when hypoxia is a major stimulus remains largely unclear. There is still insufficient evidence for the involvement of RNA interference during the early stages of vascular cell development, and particularly in the control of endothelial arterial-, venous-, and lymphatic- fate specification. Here, we show that conditional inactivation of Dicer in mice expressing Cre recombinase under the control of the tie 2 promoter causes no major alterations in EC fates and differentiation but leads to unexpected functional and morphologic alterations in the separation of blood and lymphatic vasculature.

\section{Methods}

\section{Mice}

The experiments were performed in accordance with the guidelines of the French Ministry of Agriculture. This study conforms to the standards of INSERM (the French National Institute of Health) in accordance with European Union Council Directives (86/609/EEC). All experiments were performed blindly, meaning that the experimenter was blind to the mouse genotype.Mice were backcrossed to the C57BL/6 J background for more than 10 generations. tie2-Cre:dicer ${ }^{f l+}\left(\right.$ dicer $\left.^{\Delta E C /+}\right)$ males were crossed with dicer ${ }^{f l / f l}$ females to generate embryos. The day of vaginal plug observation was considered as E0.5. Genotyping was performed on embryonic fragments using the following PCR primer pairs: Cre-R 5'-AACAGCATTGCTGTCACTTGGTCG-3' and Cre-F 5'ATTACCGGTCGATGCAACGAGTGA-3' (product size: 350-bp); DicerF1 5'-CCTGACAGTGACGGTCCAAAG-3' and DicerR1 5'-CATGACTCTTCAACTCAAACT-3' (product sizes: 420-bp dicer ${ }^{\Delta}$ allele and 351-bp wild-type dicer allele). ROSA26-R embryos were genotyped by PCR using three oligonucleotides: ROSA-1 5'AAAGTCGCTCTGAGTTGTTAT-3', ROSA-2 5'-GCGAAGAGTTTGTCCTCAACC-3' and ROSA-3 5'GGAGCGGGAGAAATGGATATG-3'. D icer ${ }^{f l+}$ and dicer ${ }^{f l f l}$ are thereafter designated as wild type (WT) embryos, dicer $^{\triangle E C /+}$ and dicer $\triangle E C / \triangle E C$ called heterozygous and mutant embryos respectively.

Efficient Cre recombinase-mediated excision of the floxed dicer allele was detected on PECAM $^{+}$endothelial cells from dicer $^{\Delta E C /+}$ and dicer ${ }^{\triangle E C / \triangle E C}$ embryos. Briefly, mouse tissues were incubated in $5 \mathrm{~mL}$ Dulbecco modified Eagle medium containing $200 \mathrm{U} / \mathrm{mL}$ collagenase I (Invitrogen) for 45 minutes at $37^{\circ} \mathrm{C}$ with occasional shaking followed by filtering through a $40-\mu \mathrm{m}$ nylon mesh. The cells were then centrifuged for 5 minutes at $4^{\circ} \mathrm{C}$, resuspended in Buffer 1 ( $0.1 \%$ bovine serum albumin, 2 mM EDTA pH 7.4 in phosphate-buffered saline) and incubated with anti rat immunoglobulin G-coated magnetic beads (Invitrogen) precoupled with rat anti-mouse platelet/endothelial cell adhesion molecule-1 (PECAM-1; MEC13.3, BD Pharmingen) for 30 minutes at $4^{\circ} \mathrm{C}$. Beads were separated using a magnetic particle concentrator (Dynal MPC-S, Invitrogen). The beads were washed $5 \times$ with Buffer 1 and centrifuged for 5 minutes at $3400 \mathrm{~g}$, and the supernatant removed as previously described [ 33]. PCR analysis was performed using primers DicerF1 and DicerDel 5'-CCTGAGCAAGGCAAGTCATTC-3'. The deletion allele produced a 471-bp PCR product whereas a wild-type allele resulted in a 1,300-bp product.

\section{X-Gal staining}

Embryos were harvested at different stages and fixed in $4 \%$ formaldehyde for $10 \mathrm{~min}$ at RT, rinsed twice in $1 \mathrm{X}$ phosphate-buffered saline, and incubated overnight at $37^{\circ} \mathrm{C}$ in buffer containing PBS $1 \mathrm{X}, 0.1 \mathrm{M}$ sodium phosphate 
(pH 7.3), 2 mM magnesium chloride, $0.02 \%$ NP-40, $0.01 \%$ sodium deoxycholate, $5 \mathrm{mM}$ potassium ferricyanide, $5 \mathrm{mM}$ potassium ferrocyanide, and $1 \mathrm{mg} / \mathrm{ml} \mathrm{X}$-gal (5-bromo-4-chloro-3-indoyl $\beta$-D-galactopyranoside).

\section{Histological analysis}

Embryos were harvested, fixed in $4 \%$ paraformaldehyde overnight and embedded in paraffin. Histologic specimen of mouse tissue was stained with hematoxylin and eosin .

\section{Immunohistochemistry}

Paraffin-embedded sections were deparaffinized, permeabilized, and incubated with goat polyclonal anti-VEGFR-3 (1:100, R\&D Systems) or anti VEGFR-2 (1:100, R\&D Systems) followed by biotin-streptavidin-HRP amplification using the Vectastain-ABC kit (Vector Lab), and post-stained with eosin.For whole-mount staining, tissues were fixed overnight in 4\% PFA and blocked overnight in blocking buffer (PBS, 5\% goat serum, $0.3 \%$ Triton X-100, and $0.2 \%$ BSA). Tissues were incubated overnight at $4^{\circ} \mathrm{C}$ with biotinylated anti-mouse LYVE-1 (1:100, R\&D Systems) or PECAM-1 (1:100, BD Biosciences) in blocking buffer followed by biotin-streptavidin-HRP amplification using the Vectastain-ABC kit.

\section{Results}

To bypass the early embryonic lethality of dicer -null mice [ 2], we developed a new Cre-loxP-mediated conditional deletion of dicer in tie2-expressing cells in order to investigate its role in vascular development. To this end, we crossed dicer -floxed mice ( dicer ${ }^{f / f l}$ ) [4] with tie2 -Cre transgenic mice [ 4, 34]. The resulting heterozygous double ${\text { transgenic mice }\left(\text { dicer }^{\Delta E C /+} \text { ) were viable. Intercrosses of dicer }\right.}^{\Delta E C /+}$ male with dicer ${ }^{f / / f}$ females yielded no dicer ${ }^{\Delta E C /}$ $\triangle E C$ pups out of 293 viable offspring at birth (see Table 1). These data suggested that mice bearing dicer gene deficiency in tie 2 -expressing cells do not survive embryogenesis. To determine when the dicer $\triangle E C / \triangle E C$ mice died, embryos were examined from E10.5 to birth. Embryos were removed and embryonic DNA was analyzed for homo- or heterogeneity of the floxed allele. This genotype was then correlated with the viability of the embryo. Mendelian ratios were observed from E10.5 to E13.5 (see Table 1). Mutant embryos from E10.5 to E11.5 were macroscopically indistinguishable from the control littermates. At later stages, E12.5 onwards, macroscopic examination revealed the presence of hemorrhages and edema in mutant embryos that increased in size and number with age (Figure $1 \mathrm{~A}$ ). Genotyping PECAM ${ }^{+}$endothelial cells showed efficient dicer inactivation in E13.5 dicer $\triangle E C / \triangle E C$ embryos compared to E13.5 dicer $\triangle E C /+$ embryos here used as controls (Figure $1 \mathrm{~B}$ ).

\section{Table 1}

Genotype analysis in percentages of live embryos resulting from the cross of a dicer ${ }^{\Delta /+}$ male with a dicer ${ }^{f / f l}$ female

\begin{tabular}{l|l|l|l}
\hline & WT & dicer $^{\text {AEC }++}$ & dicer $^{\text {AEC/AEC }}$ \\
\hline Expected ratios & $50 \%$ & $25 \%$ & $25 \%$ \\
E10.5 $n=119$ & $47.1 \%$ & $28.5 \%$ & $24.4 \%$ \\
E11.5 $n=49$ & $49 \%$ & $30.8 \%$ & $20.4 \%$ \\
E12.5 $n=31$ & $37.5 \%$ & $38.7 \%$ & $23.8 \%$ \\
E13.5 n=90 & $36.6 \%$ & $26.7 \%$ & $36.7 \%$ \\
E14.5 n=29 & $34.5 \%$ & $23.8 \%$ & $9.5 \%$ \\
E15.5 $n=4$ & $50 \%$ & $50 \%$ & $0 \%$ \\
P14 $n=293$ & $63.9 \%$ & $36.1 \%$ & $0 \%$ \\
\hline
\end{tabular}

Figure 1

Conditional deletion of dicer gene leads to hemorrhage and edema. A)Whole-mount view of WT and dicer $\triangle E C / \triangle E C$ embryos from E12.5 to E14.5. Hemorrhagic regions and edema are indicated (arrows). Scale Bar: $500 \mu \mathrm{m} . \mathrm{B}) \mathrm{PCR}$ genotyping analysis of PECAM ${ }^{+}$endothelial cells from E13.5 dicer ${ }^{\triangle E C /+}$ and dicer $\triangle E C / \triangle E C$ embryos. Detection of Cre and dicer fragments (floxed, excised and WT) are presented.

Recombination was also monitored in tie2 -expressing cells using the ROSA26 (R26) reporter line [ 35]. We then crossed the dicer $^{\Delta E C /+}$ males with homozygous dicer fl/fl $: \mathrm{R} 26 / \mathrm{R} 26$ females to generate dicer $\Delta E C /+$ :R26/+ (heterozygous, here as a control) and dicer $\triangle E C / \triangle E C: \mathrm{R} 26 /+$ (mutant) triple transgenic embryos. As indicated by wholemount X-Gal staining, the recombination was efficient in blood endothelial cells thereby allowing us to compare the pattern of the vascular network in mutant and control embryos using LacZ staining (Figure 2). Between E10.5 and $\mathrm{E} 12.5$, dicer $\triangle E C / \triangle E C$ embryos did not display obvious blood vascular defects: avascular regions were not observed in control embryos. X-Gal-stained blood vessels formed properly and vascular density was comparable in both control and mutant embryos (Figure 2). Whole-mount staining using an anti-PECAM antibody confirmed these observations as reported in Figure $3 \mathrm{~A}$ showing that vascular patterning of blood vessels was comparable to controls in E11.5 dicer $\triangle E C / \triangle E C$ embryos. In order to study the development of the blood vessel network in greater details, branchpoints of the cranial vascular network (internal carotid artery) were quantified on E11.5 embryos. The number of branchpoints in the 
internal carotid artery was not statistically different in dicer $\triangle E C / \triangle E C$ embryos compared to WT embryos (Figure $3 \mathrm{~B})$. Figure 2

Mutant embryos do not display vascular defects. A-C)Whole-mount view of X-Gal staining of dicer $^{\Delta E C /+}: \mathrm{R} 26 /+$ embryos and dicer ${ }^{\Delta E C / \triangle E C}: \mathrm{R} 26 /+$ embryos from E10.5 to E12.5. Scale Bar: $500 \mu \mathrm{m}$. The vascular network is identical in mutant and control embryos ( $\mathrm{n}=3$ for each condition).

Figure 3

Blood vessel patterning normally occurs in mutant embryos. A)Whole-mount immunohistochemical staining by antiPECAM-1 antibody on E11.5 embryos. Scale Bar: $500 \mu \mathrm{m}$. B)Branchpoints quantification (means \pm SEM) of the internal carotid artery (ica) on E11.5 embryos. The number of branchpoints is similar in WT and dicer $\triangle E C / \triangle E C$ embryos (ica; dots represent arterial branchpoints; e, eye; v, veins). (WT $\mathrm{n}=10$, dicer ${ }^{\triangle E C / \triangle E C} \mathrm{n}=5$ ).

Between E12.5 and E14.5, extensive edema gradually progressed on the back of the embryos and was sometimes filled with blood cells in dicer $\triangle E C / \triangle E C$ embryos which were all dead at E14.5 (Figure 1 and Table 1). This also phenocopies the effects observed upon genetic deletion of Prospero homeobox 1 ( prox-1 ) [ 36], Src homology domain-containing leukocyte protein-76 ( slp-76) [37] or C-type lectin-like receptor 2 ( clec-2 ) [ 38]. All show impaired lymphatic vessel development and die in utero with severe edema and hemorrhages. To establish whether dicer $\triangle E C / \triangle E C$ embryos also present defects in lymphatic vessels development, we examined transverse sections of mutant embryos. At E13.5, we never observed any disruption of the main blood vessels i.e. the thoracic aorta or the cardinal vein in $\operatorname{dicer}^{\triangle E C / \triangle E C}$ embryos (Additional file 1: Figure S1 and Figure 4). The lymph sacs, the first lymphatic structure that emerges from the cardinal vein [ 39] during development, also appeared normal (Additional file 2: Figure S2). At E13.5 however, in contrast to control embryos, these lymph sacs were filled with blood cells in dicer $\triangle E C / \triangle E C$ embryos (Figure $4 \mathrm{~A}$ ). The lymphatic identity of the blood-filled structures was confirmed by the expression of lymphatic markers VEGFR-3 (Figure 4A) and PROX-1 (Additional file 3: Figure S3). Moreover, LYVE-1 whole-mount immunostaining evidenced a complete overlap between blood-filled structures and the lymphatic vasculature in E14.5 mutant embryos (Figure 4B), confirming the blood-filled lymphatics phenotype. Figure 4

Mutant embryos present blood-filled lymphatics. A)Histological analysis of E13.5 WT and dicer $\triangle E C / \triangle E C$ embryos. dicer $^{\triangle E C / \triangle E C}$ embryos display blood-filled structures contrary to WT embryos as revealed after hematoxylin/eosin staining (HE) (upper panel). Immunostaining with the lymphatic marker VEGFR-3 confirmed the lymphatic identity of the blood filled structures (lower panel). Cv: cardinal vein, ls: lymph sac. Scale bar: $50 \mu \mathrm{m}$. ( $\mathrm{n}=2$ for each condition). B)Whole-mount view of a E14.5 dicer $\triangle E C / \triangle E C$ embryo after dissection (Left panel). Hemorrhages are indicated by $\triangle$ arrows. Immunohistochemical staining by anti-LYVE-1 antibody on the same mutant embryo (Right panel). Scale Bar: $500 \mu \mathrm{m}$. Higher magnification of the dicer $\triangle E C / \triangle E C$ embryo after dissection and after LYVE-1 staining respectively (Lower panel). There is a complete overlap between hemorrhages and LYVE-1 staining indicating blood-filled lymphatics in the dicer $\triangle E C / \triangle E C$ embryo. $(\mathrm{n}=2)$.

Altogether, these data indicate that dicer inactivation in tie2 expressing cells leads to embryonic lethality at E14.5, and to a failure in the separation of lymphatic vessels during embryonic angiogenesis.

\section{Discussion}

Here, using Cre/loxP-mediated inactivation of dicer in tie 2 -expressing cells, we demonstrate for the first time that embryonic venous-lymphatic separation is submitted to epigenetic control by RNA interference. Previous studies using a similar approach of conditional dicer deficiency using tie 2 -Cre and ve-cadherin-CRE-ERT2 have reported reduced postnatal angiogenesis but no developmental defects [15]. The likely explanation for this discrepancy probably relies on the use of a different dicer-floxed mouse leading to the presence of residual Dicer protein levels in tie 2 -Cre: dicer flff endothelial cells, reflecting an incomplete excision of the dicer allele [ 15]. Thus, these mice were hypomorphic for dicer in ECs and tie 2 -Cre: dicer ${ }^{f l f l}$ newborn litters were overtly normal and indistinguishable from their littermate controls. In contrast, in the present study, efficient dicer inactivation was evidenced in PECAM $^{+}$endothelial cells which showed complete excision of dicer in dicer $\triangle E C / \triangle E C$ embryos. The present study thus shows that dicer gene deletion in Tie2 expressing cells leads to embryonic lethality at E14.5. Mutant embryos, which display hemorrhages and edema, showed blood-filled lymphatics without evident angiogenesis defects at early stages.

We here used the well-documented tie2- Cre transgenic mice that express Cre in a pan-endothelial fashion for vascular endothelial targeting [ 34]. With the Rosa26 reporter line, we showed recombination in lymphatic vessels (Additional file 4: Figure S4). Using the same tie2- Cre ROSA26 strain, Srinivasan et al. demonstrates that at E11.5, Prox1 ${ }^{+}$endothelial cells in the anterior cardinal vein and those budding from it were lac ${ }^{+}$. Similarly, all E13.5 and E14.5 Prox $1^{+}$endothelial cells in the lymph sacs were lac $^{+}$[ 40]. Nevertheless, it should be noted that it has also been reported that tie2-Cre transgenic mice express Cre in blood island progenitors [41,42]. Recent studies have highlighted the role of hematopoietic cells during the process of separation between the venous and the lymphatic vasculature. It has been shown that podoplanin, a transmembrane protein expressed on lymphatic endothelial cells, engages the platelet receptor CLEC-2 leading to Syk-Slp-76-dependent platelet activation [ 43]. Deletion of these genes leads to aberrant vascular connection between blood and lymphatic vessels. Similar lymphovenous connections were also observed in mice deficient for the homeodomain transcription factor Meis1 (myeloid ecotropic viral integration site 1) which completely lack megakaryocyte/platelets and for the transcription factor Runx 1 which lack 
hematopoietic stem cells [ 40,44]. It should also be noted that runx1 mutant embryos, which lack platelets, present hemorrhages in the brain [ 45], which could also be observed in some dicer ${ }^{\triangle E C / \triangle E C}$ embryos. Because platelets also act to maintain vascular integrity and as the brain and lungs are more susceptible to haemorrhage in a mouse model of acute severe thrombocytopenia induced by platelet depletion [46], these hemorrhages most likely occur secondary to the lack of platelets. These data showed that platelets are required during embryonic lymphangiogenesis for the separation of the nascent lymphatic vasculature from blood vessels [ 47, 48]. However, recent studies by Yang et al. [ 49] and Hägerling et al. [ 50] have disproved a direct involment of platelets in the emergence of the first jugular lymph sacs. Podoplanin expression only starts after lymphatic endothelial cells leave the cardinal vein suggesting that platelets have a role restricted to the region where lymphatics and blood vessels coalesce, in the lymphovenous valves. Nevertheless, the presence of blood cells in lymphatic vessels may also indicate an incomplete separation of blood and lymph vessel, but could also result from de novo connections of previously separated blood and lymph vessels. Recently, Hess et al. proved that platelets interact with lymphatic endothelium valves specifically at the thoracic ductsubclavian vein junction [ 51]. Blood-filled lymphatics arise due to backfilling of the lymphatic vascular network from this site either due to a lymphovenous valve defect or due to a platelet aggregation defect. We therefore looked at the thoracic duct-subclavian vein junction and we determined that the lymphovenous valves appears normal (Additional file 5: Figure S5) suggesting a defect in platelet aggregation.

We therefore sought to decipher whether perturbing dicer expression in megakaryocytes could also reproduce a bloodfilled lymphatic phenotype during development by generating $p f 4$-cre: dicer ${ }^{f l f l}$ mice. Pf4 -cre express Cre-

recombinase in the megakaryocytic lineage as previously shown [ 52] and are a useful tool to study megakaryopoiesis, and platelet function. These mice were born at normal mendelian ratio and the separation of the lymphatic vasculature from the blood vessels was not disrupted during development (Additional file 6: Figure S6 and Table 2).

Recombination was observed in liver megakaryocytes before venous-lymphatic separation, as soon as E11.5 (data not shown) and persisted at E16.5 (Additional file 4: Figure S4B). However, the $p f 4$-Cre transgene is also partially expressed in other hematopoietic lineages and the recombination pattern during early embryogenesis is not clear [53]. A megakaryocyte specific promoter that could allow earlier deletion might be useful but does not exist.

\section{Table 2}

Genotype analysis in percentages of live pups resulting from the cross of a $p f 4$-cre: dicer ${ }^{4 /+}$ male with a dicer fl/fl female

\begin{tabular}{c|c|c|c}
\hline & WT & $\boldsymbol{p f 4}$-cre $:$ dicer & $\boldsymbol{p f 4}^{\mathbf{A}}$-cre: dicer $^{\mathbf{A / 4}}$ \\
\hline Expected ratios & $50 \%$ & $25 \%$ & $25 \%$ \\
P14 n=40 & $45 \%$ & $30 \%$ & $25 \%$ \\
\hline
\end{tabular}

Also, cells from the myeloid lineage play a critical role in this separation. Abnormal infiltration of a specific monocyte population in syk-deficient mice leads to lymphatic hyperplasia, vessel dilation and blood-lymphatic shunts [ 54]. Tie2 is expressed in the early yolk sac mesoderm suggesting that recombination may occur in hematopoietic cells [ 55]. The use of a more endothelial specific strains such as ve-cadherin-CRE-ERT2 [ 56] or pdgfb -CRE-ERT2 [ 57] would also be very useful for understanding the specific role of Dicer in the endothelium. However, the CRE activation is tamoxifen-dependent making these models more suitable for postnatal angiogenesis as recombination at a precise embryonic time point might be somewhat difficult to achieve in a very reproducible manner.

MicroRNAs are involved in many aspects of physiological and malignant hematopoiesis but surprisingly, no existing studies have focused on the role of dicer during hematopoietic development. However, dicer invalidation in adult has been described. Buza-Vidas et al. showed that dicer is required during erythroid lineage differentiation [ 58]. It was also suggested that Dicer is involved in the regulation of the hematopoietic stem cell niche as well as the regulation of hematopoietic stem cell number [ 59,60]. The blood filled phenotype that we observed could result from either a defect of hematopoiesis or a volume expansion of the blood stream indirectly affecting lymphatic development. We therefore believe that further experiments, outside of the scope of the present manuscript, will be needed to determine precisely whether hematopoiesis is modulated in dicer $\triangle E C / \triangle E C$ embryos and to fully decipher the cellular and molecular mechanisms responsible for the blood-filled lymphatic phenotype in these mice.

\section{Conclusion}

Taken together, these results show a new role for RNA interference in epigenetic control of embryonic venouslymphatic separation and provide a knowledge base for further investigations to validate functional roles for microRNAs.

Additional file 1: Figure 1: Histological analysis of E13.5 thoracic aorta in WT and dicer $\triangle E C / \triangle E C$ embryos. Immunostaining with VEGFR-2 confirmed a normal patterning of the thoracic aorta of dicer $\triangle E C / \triangle E C$ embryos. Scale Bar: $2 \mu \mathrm{m}$. $(\mathrm{n}=3)$. (JPEG $294 \mathrm{~KB})$

Additional file 2: Figure 2: Mutant embryos do not present lymph sacs defect. Whole-mount view of E12.5 WT and dicer $\triangle E C / \triangle E C$ embryos after LYVE-1 staining. The mutant embryo do not show a lymph sac defect. 
( $\mathrm{n}=3$ for each condition). (JPEG $383 \mathrm{~KB}$ )

Additional file 3: Figure 3: Prox1 expression on transversal sections of E13.5 WT and dicer $\triangle E C / \triangle E C$ embryos ( $\mathrm{n}=2$ for each condition). Prox 1 expression is maintained in lymphatics vessels in mutant embryos (upper panel), and the number of Prox 1 expressing cells is similar in WT and dicer $\triangle E C / \triangle E C$ embryos (lower panel). (JPEG $2 \mathrm{MB}$ )

Additional file 4: Figure 4: Whole-mount view of X-Gal staining of dicer $\triangle E C / \triangle E C: R 26 /+$ embryos at E13.5. Mutant embryo present recombination in lymphatic vessels (indicated by arrows). $(n=5)$. (JPEG $136 \mathrm{~KB})$

Additional file 5: Figure 5: Histological analysis of E13.5 lymphovenous valves in WT and dicer $\triangle E C / \triangle E C$ embryos (indicated by arrows). Immunostaining with VEGFR-3 showed a normal patterning and morphology of the lymphovenous valves of dicer ${ }^{A E C / \triangle E C}$ embryos. Scale Bar: $2 \mu \mathrm{m}$. ( $\mathrm{n}=2$ for each condition). (JPEG $1 \mathrm{MB}$ )

Additional file 6: Figure 6: Conditional deletion of dicer in megakaryocytes does not lead to embryonic lethality. A) Whole-mount view of WT and $p f 4$-cre: dicer ${ }^{\Delta / \Delta}$ embryos at E16.5. Mutant embryos do not present any obvious phenotype. B) Whole-mount view of X-Gal staining of a $p f 4$-cre: dicer ${ }^{4 / \Delta}$ liver at E16.5 (Left panel). Histological analysis of the same E16.5 liver (Right panel). Recombination occurs in typical large megakaryocytes in the liver. $(n=3)$. (JPEG 1 MB)

\section{Abbreviations}

- CLEC-2:

C-type lectin-like receptor 2

- Cv:

Cardinal vein

- E:

Embryonic day

- Ica:

Internal carotid artery

- Ls:

Lymph sac

- miRNA:

microRNA

- mRNA:

Messenger RNA

- Pecam-1:

Platelet endothelial cell adhesion molecule 1

- siRNA:

Short interfering RNA

- Vegfr-3:

Vascular endothelial growth factor receptor 3

- WT:

Wild type.

\section{Declarations}

\section{Acknowledgements}

This work has received support under the program «Investissements d'Avenir » launched by the French Government and implemented by the ANR, with the references:

\section{Authors' original submitted files for images}

Below are the links to the authors' original submitted files for images.

Authors' original file for figure 1

Authors' original file for figure 2

Authors' original file for figure 3

Authors' original file for figure 4

\section{Competing interests}

The authors declare that they have no competing interests. 
SGe, SGa designed experiments. SGa, JP and ML performed experiments. SGe, SGa, IG and MT wrote the paper. All authors read and approved the final manuscript.

\section{References}

1. Ketting RF. The many faces of RNAi. Dev Cell. 2011;20:148-161.

View Article Google Scholar

2. Bernstein E, Kim SY, Carmell MA, Murchison EP, Alcorn H, Li MZ, Mills AA, Elledge SJ, Anderson KV, Hannon GJ. Dicer is essential for mouse development. Nat Genet. 2003;35:215-217.

View Article Google Scholar

3. Yang WJ, Yang DD, Na S, Sandusky GE, Zhang Q, Zhao G. Dicer is required for embryonic angiogenesis during mouse development. J Biol Chem. 2005;280:9330-9335.

View Article Google Scholar

4. Harfe BD McManus MT Mansfield JH Hornstein E Tabin CJ The RNaseIII enzyme Dicer is required for morphogenesis but not patterning of the vertebrate limb Proc Natl Acad Sci U S A 200510210898 109031182454 10.1073/pnas.0504834102

5. Cobb BS Nesterova TB Thompson E Hertweck A O'Connor E Godwin J Wilson CB Brockdorff N Fisher AG Smale ST Merkenschlager M T cell lineage choice and differentiation in the absence of the RNase III enzyme Dicer J Exp Med 2005201136713732213187 10.1084/jem.20050572

6. Chen JF Murchison EP Tang R Callis TE Tatsuguchi M Deng Z Rojas M Hammond SM Schneider MD Selzman CH Meissner G Patterson C Hannon GJ Wang DZ Targeted deletion of Dicer in the heart leads to dilated cardiomyopathy and heart failure Proc Natl Acad Sci USA 20081052111 $2116254287010.1073 /$ pnas.0710228105

7. Otsuka M, Zheng M, Hayashi M, Lee JD, Yoshino O, Lin S, Han J. Impaired microRNA processing causes corpus luteum insufficiency and infertility in mice. J Clin Invest. 1944-1954;2008:118-.

View Article Google Scholar

8. Albinsson S Skoura A Yu J DiLorenzo A Fernandez-Hernando C Offermanns S Miano JM Sessa WC Smooth muscle miRNAs are critical for post-natal regulation of blood pressure and vascular function PLoS One 20116 e188693081311 10.1371/journal.pone.0018869

9. Albinsson S Suarez Y Skoura A Offermanns S Miano JM Sessa WC MicroRNAs are necessary for vascular smooth muscle growth, differentiation, and function Arterioscler Thromb Vasc Biol 201030 111811262880481 10.1161/ATVBAHA.109.200873

10. Albinsson S Sessa WC Can microRNAs control vascular smooth muscle phenotypic modulation and the response to injury? Physiol Genomics 2011435295333110893

10.1152/physiolgenomics.00146.2010

11. Boettger T Beetz N Kostin S Schneider J Kruger M Hein L Braun T Acquisition of the contractile phenotype by murine arterial smooth muscle cells depends on the Mir143/145 gene cluster J Clin Invest 2009119263426472735940 10.1172/JCI38864

12. Cheng Y Liu X Yang J Lin Y Xu DZ Lu Q Deitch EA Huo Y Delphin ES Zhang C MicroRNA-145, a novel smooth muscle cell phenotypic marker and modulator, controls vascular neointimal lesion formation Circ Res 20091051581662728297 10.1161/CIRCRESAHA.109.197517

13. Xin M Small EM Sutherland LB Qi X McAnally J Plato CF Richardson JA Bassel-Duby R Olson EN MicroRNAs miR-143 and miR-145 modulate cytoskeletal dynamics and responsiveness of smooth muscle cells to injury Genes Dev 200923216621782751981 10.1101/gad.1842409

14. Kuehbacher A, Urbich C, Zeiher AM, Dimmeler S. Role of Dicer and Drosha for endothelial microRNA expression and angiogenesis. Circ Res. 2007;101:59-68.

View Article Google Scholar 
15. Suarez Y Fernandez-Hernando C Yu J Gerber SA Harrison KD Pober JS Iruela-Arispe ML Merkenschlager M Sessa WC Dicer-dependent endothelial microRNAs are necessary for postnatal angiogenesis Proc Natl Acad Sci USA 200810514082 140872544582 10.1073/pnas.0804597105

16. Heusschen R, van Gink M, Griffioen AW, Thijssen VL. MicroRNAs in the tumor endothelium: novel controls on the angioregulatory switchboard. Biochim Biophys Acta. 1805;2010:87-96.

View Article Google Scholar

17. Poliseno L, Tuccoli A, Mariani L, Evangelista M, Citti L, Woods K, Mercatanti A, Hammond S, Rainaldi G. MicroRNAs modulate the angiogenic properties of HUVECs. Blood. 2006;108:3068-3071.

View Article Google Scholar

18. Kuehbacher A, Urbich C, Dimmeler S. Targeting microRNA expression to regulate angiogenesis. Trends Pharmacol Sci. 2008;29:12-15.

View Article Google Scholar

19. Landskroner-Eiger S Moneke I Sessa WC miRNAs as modulators of angiogenesis Cold Spring Harbor perspectives in medicine 20133 a0066433552340 10.1101/cshperspect.a006643

20. Suarez Y, Fernandez-Hernando C, Pober JS, Sessa WC. Dicer dependent microRNAs regulate gene expression and functions in human endothelial cells. Circ Res. 2007;100:1164-1173.

View Article Google Scholar

21. Suarez Y Sessa WC MicroRNAs as novel regulators of angiogenesis Circ Res 2009104442 4542760389 10.1161/CIRCRESAHA.108.191270

22. Bonauer A, Carmona G, Iwasaki M, Mione M, Koyanagi M, Fischer A, Burchfield J, Fox H, Doebele C, Ohtani K, Chavakis E, Potente M, Tjwa M, Urbich C, Zeiher AM, Dimmeler S. MicroRNA-92a controls angiogenesis and functional recovery of ischemic tissues in mice. Science. 2009;324:1710-1713. View Article Google Scholar

23. Doebele C, Bonauer A, Fischer A, Scholz A, Reiss Y, Urbich C, Hofmann WK, Zeiher AM, Dimmeler S. Members of the microRNA-17-92 cluster exhibit a cell-intrinsic antiangiogenic function in endothelial cells. Blood. 2010;115:4944-4950.

View Article Google Scholar

24. Fish JE Santoro MM Morton SU Yu S Yeh RF Wythe JD Ivey KN Bruneau BG Stainier DY Srivastava D miR-126 regulates angiogenic signaling and vascular integrity Dev Cell 2008152722842604134 10.1016/j.devcel.2008.07.008

25. Hinkel R, Penzkofer D, Zuhlke S, Fischer A, Husada W, Xu QF, Baloch E, van Rooij E, Zeiher AM, Kupatt C, Dimmeler S. Inhibition of MicroRNA-92a Protects Against Ischemia/Reperfusion Injury in a LargeAnimal Model. Circulation. 2013;128:1066-1075.

View Article Google Scholar

26. Kuhnert F, Mancuso MR, Hampton J, Stankunas K, Asano T, Chen CZ, Kuo CJ. Attribution of vascular phenotypes of the murine Egfl7 locus to the microRNA miR-126. Development. 2008;135:3989-3993. View Article Google Scholar

27. Wang S Aurora AB Johnson BA Qi X McAnally J Hill JA Richardson JA Bassel-Duby R Olson EN The endothelial-specific microRNA miR-126 governs vascular integrity and angiogenesis Dev Cell 2008152612712685763 10.1016/j.devcel.2008.07.002

28. Yin KJ Olsen K Hamblin M Zhang J Schwendeman SP Chen YE Vascular endothelial cell-specific microRNA-15a inhibits angiogenesis in hindlimb ischemia J Biol Chem 201228727055 270643411046 10.1074/jbc.M112.364414

29. Kane NM Howard L Descamps B Meloni M McClure J Lu R McCahill A Breen C Mackenzie RM Delles C Mountford JC Milligan G Emanueli C Baker AH Role of microRNAs 99b, 181a, and 181b in the differentiation of human embryonic stem cells to vascular endothelial cells Stem Cells 201230643 6543490385 10.1002/stem.1026 
30. Fasanaro P D'Alessandra Y Di Stefano V Melchionna R Romani S Pompilio G Capogrossi MC Martelli F MicroRNA-210 modulates endothelial cell response to hypoxia and inhibits the receptor tyrosine kinase ligand Ephrin-A3 J Biol Chem 200828315878158833259646

10.1074/jbc.M800731200

31. Fasanaro P Greco S Lorenzi M Pescatori M Brioschi M Kulshreshtha R Banfi C Stubbs A Calin GA Ivan M Capogrossi MC Martelli F An integrated approach for experimental target identification of hypoxia-induced miR-210 J Biol Chem 200928435134351432787374 10.1074/jbc.M109.052779

32. Kazenwadel J, Michael MZ, Harvey NL. Prox 1 expression is negatively regulated by miR-181 in endothelial cells. Blood. 2010;116:2395-2401.

View Article Google Scholar

33. del Toro R Prahst C Mathivet T Siegfried G Kaminker JS Larrivee B Breant C Duarte A Takakura N Fukamizu A Penninger J Eichmann A Identification and functional analysis of endothelial tip cellenriched genes Blood 2010116402540334314527 10.1182/blood-2010-02-270819

34. Kisanuki YY, Hammer RE, Miyazaki J, Williams SC, Richardson JA, Yanagisawa M. Tie2-Cre transgenic mice: a new model for endothelial cell-lineage analysis in vivo. Dev Biol. 2001;230:230-242.

View Article Google Scholar

35. Soriano P. Generalized lacZ expression with the ROSA26 Cre reporter strain. Nat Genet. 1999;21:70-71. View Article Google Scholar

36. Wigle JT, Oliver G. Prox1 function is required for the development of the murine lymphatic system. Cell. 1999;98:769-778.

View Article Google Scholar

37. Abtahian F Guerriero A Sebzda E Lu MM Zhou R Mocsai A Myers EE Huang B Jackson DG Ferrari VA Tybulewicz V Lowell CA Lepore JJ Koretzky GA Kahn ML Regulation of blood and lymphatic vascular separation by signaling proteins SLP-76 and Syk Science 20032992472512982679 $10.1126 /$ science. 1079477

38. Suzuki-Inoue K Inoue O Ding G Nishimura S Hokamura K Eto K Kashiwagi H Tomiyama Y Yatomi Y Umemura K Shin Y Hirashima M Ozaki Y Essential in vivo roles of the C-type lectin receptor CLEC-2: embryonic/neonatal lethality of CLEC-2-deficient mice by blood/lymphatic misconnections and impaired thrombus formation of CLEC-2-deficient platelets J Biol Chem 201028524494 245072915686 10.1074/jbc.M110.130575

39. Wang Y Oliver G Current views on the function of the lymphatic vasculature in health and disease Genes Dev 201024211521262947764 10.1101/gad.1955910

40. Srinivasan RS Dillard ME Lagutin OV Lin FJ Tsai S Tsai MJ Samokhvalov IM Oliver G Lineage tracing demonstrates the venous origin of the mammalian lymphatic vasculature Genes Dev 200721 $24222432199387310.1101 / \operatorname{gad} .1588407$

41. Li W, Ferkowicz MJ, Johnson SA, Shelley WC, Yoder MC. Endothelial cells in the early murine yolk sac give rise to CD41-expressing hematopoietic cells. Stem Cells Dev. 2005;14:44-54.

View Article Google Scholar

42. Lancrin C Sroczynska P Stephenson C Allen T Kouskoff V Lacaud G The haemangioblast generates haematopoietic cells through a haemogenic endothelium stage Nature 20094578928952661201 10.1038/nature07679

43. Bertozzi CC Hess PR Kahn ML Platelets: covert regulators of lymphatic development Arterioscler Thromb Vasc Biol 201030236823712994722 10.1161/ATVBAHA.110.217281

44. Carramolino L, Fuentes J, Garcia-Andres C, Azcoitia V, Riethmacher D, Torres M. Platelets play an essential role in separating the blood and lymphatic vasculatures during embryonic angiogenesis. Circ Res. 2010;106:1197-1201.

View Article Google Scholar 
45. Okuda T, van Deursen J, Hiebert SW, Grosveld G, Downing JR. AML1, the target of multiple chromosomal translocations in human leukemia, is essential for normal fetal liver hematopoiesis. Cell. 1996;84:321330 .

View Article Google Scholar

46. Goerge T Ho-Tin-Noe B Carbo C Benarafa C Remold-O’Donnell E Zhao BQ Cifuni SM Wagner DD Inflammation induces hemorrhage in thrombocytopenia Blood 2008111495849642384127 10.1182/blood-2007-11-123620

47. Uhrin P, Zaujec J, Breuss JM, Olcaydu D, Chrenek P, Stockinger H, Fuertbauer E, Moser M, Haiko P, Fassler R, Alitalo K, Binder BR, Kerjaschki D. Novel function for blood platelets and podoplanin in developmental separation of blood and lymphatic circulation. Blood. 2010;115:3997-4005.

View Article Google Scholar

48. Bertozzi CC Schmaier AA Mericko P Hess PR Zou Z Chen M Chen CY Xu B Lu MM Zhou D Sebzda E Santore MT Merianos DJ Stadtfeld M Flake AW Graf T Skoda R Maltzman JS Koretzky GA Kahn ML Platelets regulate lymphatic vascular development through CLEC-2-SLP-76 signaling Blood 2010 1166616703324297 10.1182/blood-2010-02-270876

49. Yang Y Garcia-Verdugo JM Soriano-Navarro M Srinivasan RS Scallan JP Singh MK Epstein JA Oliver G Lymphatic endothelial progenitors bud from the cardinal vein and intersomitic vessels in mammalian embryos Blood 2012120234023483447786 10.1182/blood-2012-05-428607

50. Hagerling R Pollmann C Andreas M Schmidt C Nurmi H Adams RH Alitalo K Andresen V SchulteMerker S Kiefer F A novel multistep mechanism for initial lymphangiogenesis in mouse embryos based on ultramicroscopy EMBO J 2013326296443590982 10.1038/emboj.2012.340

51. Hess PR Rawnsley DR Jakus Z Yang Y Sweet DT Fu J Herzog B Lu M Nieswandt B Oliver G Makinen T Xia L Kahn ML Platelets mediate lymphovenous hemostasis to maintain blood-lymphatic separation throughout life J Clin Invest 20141242732843871239 10.1172/JCI70422

52. Tiedt R, Schomber T, Hao-Shen H, Skoda RC. Pf4-Cre transgenic mice allow the generation of lineagerestricted gene knockouts for studying megakaryocyte and platelet function in vivo. Blood. 2007;109:1503-1506.

View Article Google Scholar

53. Calaminus SD Guitart AV Sinclair A Schachtner H Watson SP Holyoake TL Kranc KR Machesky LM Lineage tracing of Pf4-Cre marks hematopoietic stem cells and their progeny PLoS One 20127 e513613531453 10.1371/journal.pone.0051361

54. Bohmer R, Neuhaus B, Buhren S, Zhang D, Stehling M, Bock B, Kiefer F. Regulation of developmental lymphangiogenesis by Syk(+) leukocytes. Dev Cell. 2010;18:437-449.

View Article Google Scholar

55. Ema M, Yokomizo T, Wakamatsu A, Terunuma T, Yamamoto M, Takahashi S. Primitive erythropoiesis from mesodermal precursors expressing VE-cadherin, PECAM-1, Tie2, endoglin, and CD34 in the mouse embryo. Blood. 2006;108:4018-4024.

View Article Google Scholar

56. Pitulescu ME, Schmidt I, Benedito R, Adams RH. Inducible gene targeting in the neonatal vasculature and analysis of retinal angiogenesis in mice. Nat Protoc. 2010;5:1518-1534.

View Article Google Scholar

57. Claxton S, Kostourou V, Jadeja S, Chambon P, Hodivala-Dilke K, Fruttiger M. Efficient, inducible Crerecombinase activation in vascular endothelium. Genesis. 2008;46:74-80.

View Article Google Scholar

58. Buza-Vidas N, Cismasiu VB, Moore S, Mead AJ, Woll PS, Lutteropp M, Melchiori L, Luc S, Bouriez-Jones T, Atkinson D, O'Carroll D, Jacobsen SE, Nerlov C. Dicer is selectively important for the earliest stages of erythroid development. Blood. 2012;120:2412-2416.

View Article Google Scholar 
59. Guo S Lu J Schlanger R Zhang H Wang JY Fox MC Purton LE Fleming HH Cobb B Merkenschlager M Golub TR Scadden DT MicroRNA miR-125a controls hematopoietic stem cell number Proc Natl Acad Sci USA 201010714229142342922532 10.1073/pnas.0913574107

60. Raaijmakers MH Mukherjee S Guo S Zhang S Kobayashi T Schoonmaker JA Ebert BL Al-Shahrour F Hasserjian RP Scadden EO Aung Z Matza M Merkenschlager M Lin C Rommens JM Scadden DT Bone progenitor dysfunction induces myelodysplasia and secondary leukaemia Nature 2010464852 $857342286310.1038 /$ nature08851 